\title{
sciendo
}

\section{The impact of foreign capital inflows on poverty in Vietnam: An empirical investigation}

\author{
Mercy T. Musakwa \\ University of South Africa, South Africa, tsile.musa@gmail.com \\ Nicholas M. Odhiambo \\ University of South Africa, South Africa, odhiamn@unisa.ac.za \\ Sheilla Nyasha \\ University of South Africa, South Africa, sheillanyasha@gmail.com
}

\begin{abstract}
This study investigates the impact of foreign capital inflows on poverty in Vietnam, using annual time series data from 1990 to 2018. The study was motivated by the need to establish if burgeoning foreign capital inflows in Vietnam can support the poverty alleviation agenda. Foreign direct investment (FDI) and external debt were used as proxies for foreign capital inflows; and infant mortality rate, Human Development Index (HDI) and household consumption expenditure were used as poverty proxies. Using the autoregressive distributed lag (ARDL) approach, the study found foreign direct investment to reduce poverty in the short run and long run when household consumption expenditure was used as a poverty measure. However, the study found FDI to worsen poverty in the short run when infant mortality rate and HDI were used as poverty proxies. The study found external debt to have poverty mitigating effect in the short run regardless of the poverty measure used and in the long run only when household consumption expenditure was used as a poverty measure.
\end{abstract}

Keywords: autoregressive distributed lag (ARDL), external debt, foreign direct investment, poverty, Vietnam.

JEL classification: F21, 132.

DOI: 10.2478/crebss-2021-0008

Received: July 13, 2021

Accepted: September 28, 2021

\section{Introduction}

Vietnam is among one of the signatories to the Sustainable Development Goals (SDGs), a successor to the Millennium Development Goals that ended in 2015. The step that was taken by Vietnam to sign the agreement implies a consented government effort to meet the 17 SDGs. Among the SDGs is poverty reduction, which gives Vietnam the pressure to continue seeking ways to reduce poverty. Vietnam 
has integrated the SDGs in the Socio-Economic Development Plans (SEDPs) focused on changing strategies and actions by ministers, provinces, and agencies (SDG Business Hub, 2020). The adoption of the Doi Moi in 1986 marked a turning point in Vietnam economic development and poverty reduction journey. The Doi Moi policies slowly but surely transformed Vietnam from a centrally planned economy into a market-oriented economy (Steer, 2020). Despite the spate of economic growth, coupled with poverty reduction, some regions in Vietnam still lag behind, with high poverty levels among the minority and ethnic groups (Steer, 2020).

Vietnam has made strides in reducing poverty, although the war against poverty is far from being over (Quyen, 2019). A cocktail of targeted poverty reduction programmes, such as, P-135, Hunger and Poverty Programme and the NTP-PR health insurance for the poor; P-132 and P-134 - targeting Central Highlands to improve land ownership and housing conditions (Quyen, 2019) were rolled out. The poverty levels in Vietnam fell gradually, for instance, poverty headcount measured at $\$ 1.90$ declined from $52.9 \%$ in 1992 to $1.9 \%$ in 2018 (World Bank, 2020). This coincides with the time that Vietnam experienced a surge in FDI from $2.7 \%$ of gross domestic product (GDP) in 1990 to 6.3\% in 2018 (World Bank, 2020). These developments have motivated this study to investigate whether Vietnam can benefit from the burgeoning foreign capital inflows in the fight against poverty.

The relationship between poverty and other macroeconomic variables has attracted attention from researchers in recent years due to the renewed efforts on poverty reduction spearheaded by the United Nations. Further, the SDGs also advocate mobilisation of resources from domestic and foreign sources to support sustainable development, especially in developing countries. A re-examination of the factors that help in the formulation of effective policies that achieve desired results of poverty reduction in Vietnam is pertinent. Among the studies that investigated the impact of external debt on poverty, there is overwhelming evidence of a positive impact of external debt on poverty (see Zaghdoudi and Hakimi, 2017; Akram, 2016; Oyedele, Emarah and Ogege, 2013). However, the same cannot be said with studies that have investigated the impact of FDI on poverty. The findings are divided among those that found a negative impact between the two (for example, Magombeyi and Odhiambo, 2018a; Soumare, 2015); those that found FDI to have no significant impact on poverty (Magombeyi and Odhiambo, 2018b); and those that found a positive impact of FDI on poverty (see Anetor, Esho and Verhoef, 2020). However, the scale is tilted towards the negative impact of FDI on poverty.

To improve the robustness of the results, this study uses three poverty proxies namely: infant mortality rate, which is a health poverty measure; household consumption expenditure, an income measure of poverty; and Human Development Index (HDI), a multidimensional measure of poverty. The study also uses two measures of foreign capital inflows, namely: foreign direct investment and external debt. Extant literature has examined the impact of the two foreign capital flows on poverty using one poverty proxy. Given the multidimensional nature of poverty, one poverty proxy may not give the true reflection of the relationship between capital inflows and poverty. This study departs from other studies by employing poverty proxies that capture varied dimensions of poverty that may alter the findings made in previous studies. Further, the impact of foreign capital flows on poverty is examined using the autoregressive distributed lag (ARDL) bounds approach, which gives the relationship in short run and long run time frames. This is useful in informing policy as it guides on timeframes (short run or long run) that 
capital inflows are most effective in reducing poverty. Apart from the long-run and short-run results, the ARDL approach has numerous advantages.

Vietnam was selected for this study because it is one of the signatories to the SDGs, hence findings from this study will inform poverty related policies. The question this study seeks to answer is whether Vietnam can harness the capital inflows to reduce poverty apart from high economic growth that has been experienced in the country; hence the objective of this study is to empirically examine the impact of capital inflows on poverty levels in Vietnam. The rest of the paper is structured as follows: Section two reviews related literature. Section three outlines the estimation techniques. The fourth section presents data analysis and the results, while the fifth section concludes the study.

\section{Review of related literature Country-based literature}

Vietnam adopted the accelerated economic growth through the Five-Year SocioEconomic Development Plans. The current development plan covers 2016-2020 (IMF, 2006). The first Five-Year Social Economic Development Plan was rolled out in 20012005 (IMF, 2006). The commitment of the Viennese government to poverty reduction was shown by a draft of a poverty reduction and growth strategy (German Development Institute, 2020). The Comprehensive Poverty Reduction and Growth Strategy (CPRGS) in Vietnam seeks to address the three dimensions of poverty, namely, opportunity, empowerment, and security (German Development Institute, 2020). The strategy aims to support high economic growth coupled with poverty reduction.

Vietnam implemented targeted poverty reduction policies to accelerate poverty reduction in the poorest districts and improve the livelihoods of the poor, especially the ethnic minority groups (UNDP, 2012). The P-135 and P-130 programmes targeted an improvement in living conditions of ethnic minorities; while P-132 and P-134 targeted Central Highlands to increase access to means of production, land, and improve housing conditions (UNDP, 2012). Further, targeted poverty reduction programmes also included the Hunger and Poverty Eradication Program (HEPR) and the health insurance for the poor 'NTP-PR' (UNDP, 2012). These programs have provided an opportunity for the poor to have access to the means of production and good health. Vietnam emerged to be one of the fast-growing countries, moving from a centralised economic system to an open economy. The government made great progress on economic development and poverty reduction through the Doi Moi that had encompassing reform programmes. The achievement of the Doi Moi is evident through the Vietnamese economic transformation from a low-income country to a lower-middle income country (UNDP, 2012).

In response to a suit of economic and poverty reduction policies that were implemented in Vietnam, poverty declined drastically from $52.9 \%$ in 1992 to $1.9 \%$ in 2018, when poverty headcount measure of $\$ 1.90$ per day is used (World Bank, 2020). The same trend is also mimicked when poverty is measured by poverty gap. The poverty gap, when measured at $\$ 1.90$ per day, declined from $16.5 \%$ in 1992 to $0.9 \%$ in 2018 (World Bank, 2020). Overall, Vietnam made great strides in poverty reduction as exhibited by poverty gap measured at $\$ 3.20$ and $\$ 5.50$, where single digits were recorded in 2018 (World Bank, 2020). Vietnam is among the success stories on the fight against poverty. Nevertheless, Vietnam is still pressing on with poverty reduction, especially among the ethnic minority groups under the Sustainable Development 
auspices. Figure 1 shows the trends in poverty when measured by poverty headcount and poverty gap whereas Figure 2 presents the trends in Human Development Index (HDI) covering a period from 1990 to 2018.

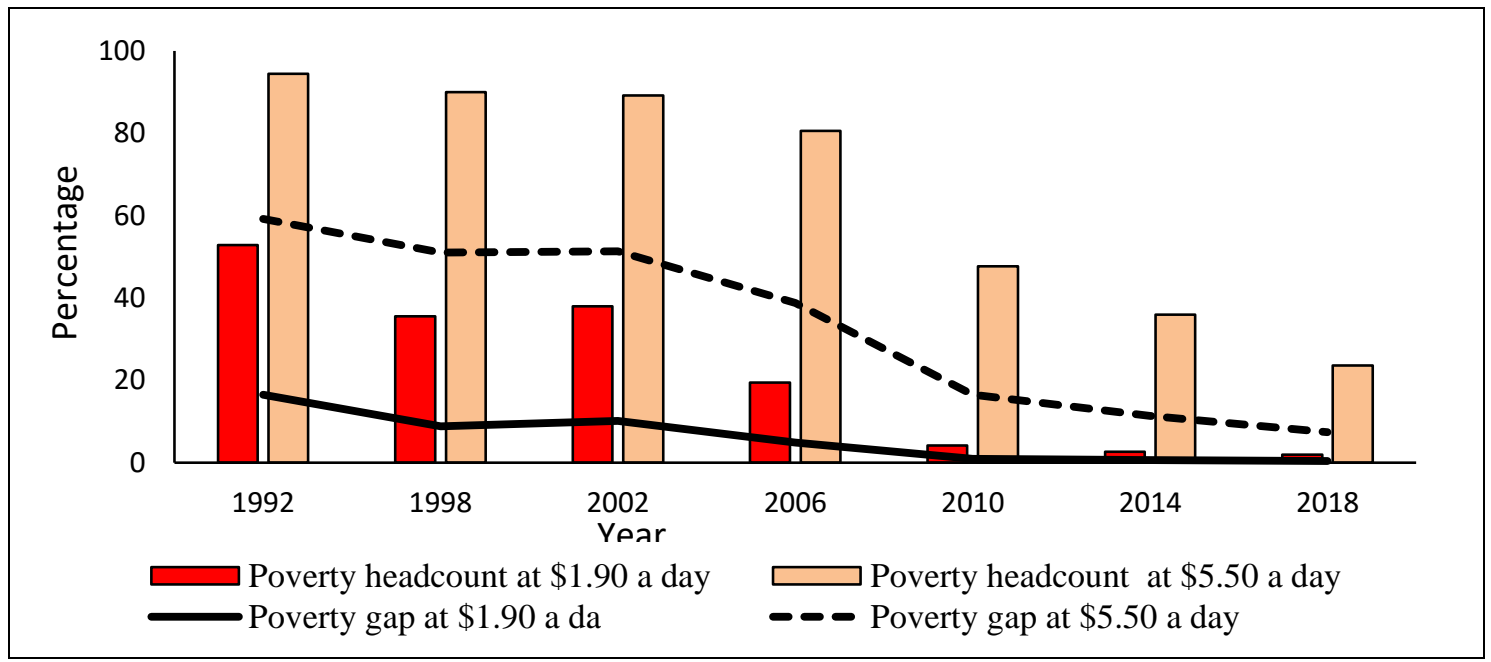

Figure 1 Trends in poverty measures

Source: World Bank, 2020.

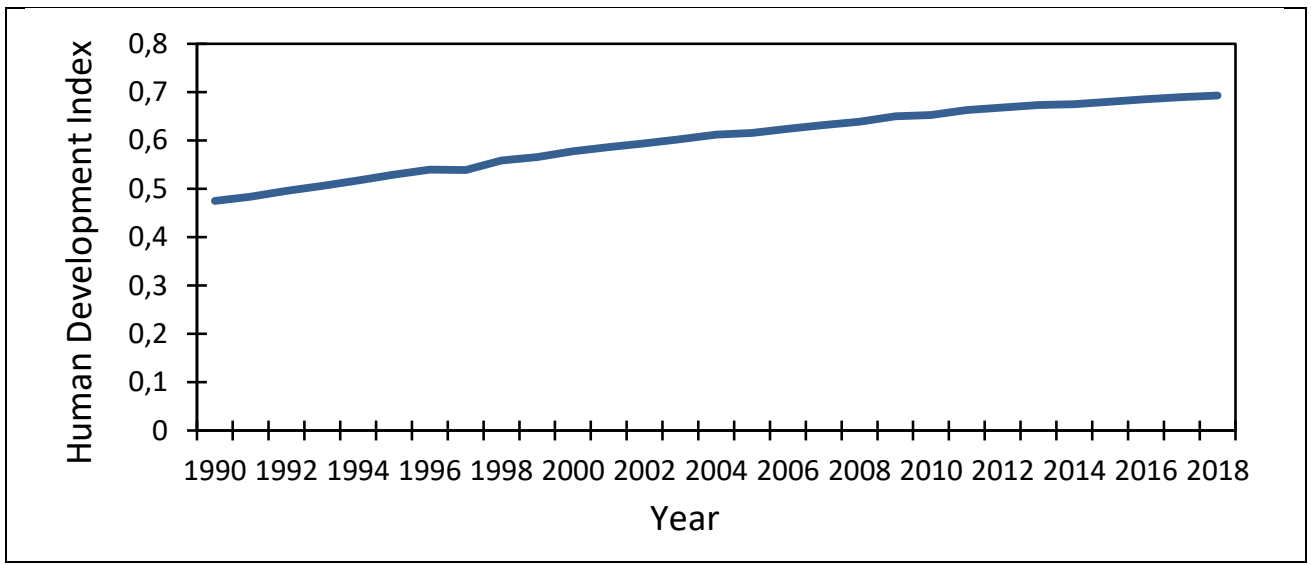

Figure 2 Trends in Human Development Index

Source: UNDP, 2020.

Poverty measured by the HDI improved steadily over the years as the country rolled out different policy packages targeted at accelerating economic growth, employment, and integration into the world economy. The HDI improved from 0.48 in 1990 to 0.69 in 2018, putting the country in the medium human development category (UNDP, 2020).

On the foreign capital front, the five-year plans that were implemented in Vietnam resulted in the country opening its economy, embracing market-based economy from a central system, attracting foreign capital inflows. The country established foreign relations and increased international commitments with international financial organisations (IMF, 2006). The opening up of the economy resulted in Vietnam signing a number of multilateral and bilateral agreements (IMF, 2006). Vietnam actively advanced interest in FDI inflows in the late 1980s under the Doi Moi policy (United Nations Conference on Trade and Development 'UNCTAD', 2008). This resulted in a transition of Vietnam from an isolated country that was 
centrally planned in the 1970s, into a dynamic and diversified economy integrated into the world economy in the 2000s (UNCTAD, 2008). The Doi Moi has gradually led to private participation in the economy and opening up of the economy to FDI (UNCTAD, 2008).

Vietnam joined a number of economic and trade agreements, such as the World Trade Organisation (WTO) in 2007 and the Asia-Pacific Economic Cooperation (APEC) in 1998 (UNCTAD, 2008). The Doi Moi policy gradually resulted in an increase in FDI inflows from 1987 (UNCTAD, 2008). The FDI has created employment, and has trained a number of people, thus building human capital (UNCTAD, 2008). Although reforms started with the Doi Moi in 1986, full gear legal and regulatory reforms came into effect with the negotiation for the accession to WTO in 1995 (UNCTAD, 2008). A number of reforms were done as a prerequisite to the accession to WTO in 2007 (UNCTAD, 2008). A major shift came with adoption of the Law on Investment and a new Law on Enterprises that strived to put domestic and foreign investors on the same footing (UNCTAD, 2008). Overall, measures implemented to attract FDI focused on boosting investment capital, technology transfer, creation of jobs and enhancing management skills (Steer, 2020).

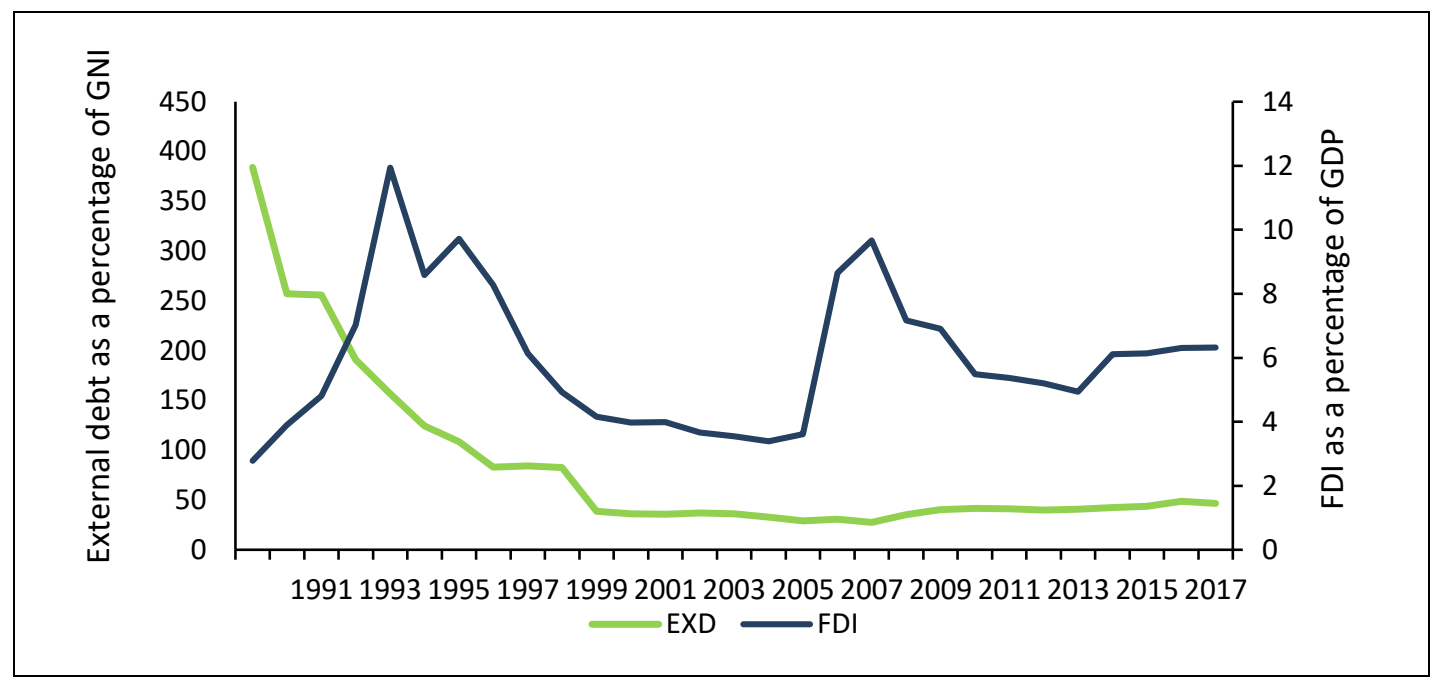

Figure 3 Trends in foreign capital inflows in Vietnam

Source: World Bank, 2020.

Foreign direct investment inflows into Vietnam were sluggish from 1980 but picked gradually from 1987, only to register significant inflows in 1990, where FDI as a percentage of GDP of $2.8 \%$ was received (World Bank, 2020). The inflow of FDI consistently increased and reached a peak in 1994 at $11.9 \%$, before declining and maintaining an average of $6 \%$ until 2018 (World Bank, 2020). The opening up of the economy coincided with the surge in FDI (World Bank, 2020). Vietnam recorded an average of $73.8 \%$ of external debt stock as a percentage of $\mathrm{GNI}$, with the most weight coming from 1991 to 1996 - the years of high external debt stock (World Bank, 2020). Figure 3 shows the trend in FDI and external debt from 1990.

\section{Theoretical and empirical literature review}

The impact of external debt on poverty is indirect, through economic growth and reduction of resources available to the government to support social and economic activities such as social safety nets (Loko et al., 2003). Further, high external debt is expected to slow economic growth through reduction in investment described in 
debt overhang as larger and larger resources are channeled towards debt service (Krugman, 1988). Another debt overhang postulation explores the increased expectation that a large debt stock will be financed through the distortionary measures, such as inflation tax. Investors react by postponing or choosing other highrisk investments. The Debt Laffer curve illustrates that after a certain level of tax adjustment, beyond a given point, tax revenue begins to decline due to the factors described in the two strands of literature that explain debt overhang.

The linkage between FDI and poverty can be explained through direct and indirect relationships. The indirect relationship is achieved through economic growth where horizontal and vertical spill over from FDI firms support upstream and downstream local firms, resulting in an increase in output; technological advancement; enhanced marketing and management skills; and employment (Magombeyi \& Odhiambo, 2017; Meyer, 2004; Gorg and Greenaway, 2004). The direct effect is achieved through the increase in government revenue as the FDI firm pays taxes. The overall impact of taxes paid by FDI subsidiaries depends on the net effect of the incentives that are given by government to attract them (Magombeyi \& Odhiambo, 2017).

There is vast literature that has explored the impact of external debt on economic growth and that of FDI on economic growth. It is only in recent years that the attention of researchers shifted to explore a possible relationship between these two foreign capital inflows and poverty. This was heightened by the United Nations initiative on the Millennium Development Goals and the current Sustainable Development Goals that set targets on a plethora of sustainable development metrics in various social and economic areas. Among the studies that investigated the impact of external debt on poverty, there is overwhelming evidence of a positive impact of external debt on poverty (see Zaghdoudi and Hakimi, 2017; Akram, 2016; Oyedele et al., 2013; Loko et al., 2003), while those studies that explored the impact of FDI on poverty found mixed results with the scale tilted towards a poverty reducing effect of FDI (see, Magombeyi and Odhiambo, 2018a; 2018b; Soumare, 2015; Gohou and Soumare, 2012).

Zaghdoudi and Hakimi (2017) investigated the impact of external debt on poverty in a study on 25 developing countries using data from $2000-2015$. The study used poverty headcount of $\$ 3.10$ a day and external debt as a percentage of GNI. Employing a panel cointegration model, a strong positive impact was confirmed between poverty and external debt. Akram (2016) investigated the impact of public debt on economic growth and poverty in Bangladesh, India, Pakistan, and Sri Lanka. Using standard panel data, the study found that public external debt or external debt servicing has an insignificant relationship with income inequality.

Oyedele et al., (2013) investigated the impact of debt on poverty in Nigeria using a multiple regression analysis. Poverty was measured by public expenditure on social goods and services to GDP, while debt was measured by external debt to GDP. In the study, external debt and debt servicing were found to cause poverty. Loko et al. (2003) analysed the effect of external debt on poverty in low-income countries, using the general method of moments (GMM). Poverty proxies used in the study were life expectancy, infant mortality rate and gross primary enrolment rates. In the study, external debt was found to have limited adverse effect on non-income poverty indicators - life expectancy and infant mortality rate.

Studies that have investigated the impact of FDI on poverty have found mixed results. Some studies found a positive impact (see, Magombeyi and Odhiambo, 2018a; 2018b; Soumare, 2015; Gohou and Soumare, 2012), while others found a 
negative impact of FDI on poverty (see, Anetor et al., 2020; Huang, Teng and Tsai, 2010). The last category of studies found FDI to have no impact on poverty (see, for example Akinmulegun, 2012). The findings from these studies affirm the need for a country-by-country study on the relationship between FDI and poverty, thus, making another study on Vietnam important in informing policy choices that are effective in reducing poverty.

Magombeyi and Odhiambo (2018a) in a study on South Africa, using infant mortality rate, household consumption expenditure and life expectancy as proxies for poverty, found FDI to have a positive impact on poverty reduction when poverty was measured by infant mortality rate. In the same study, FDI was found to have no impact on poverty when household consumption expenditure and life expectancy were used as poverty proxies. Magombeyi and Odhiambo (2018b) investigated the impact of FDI on poverty in Botswana using the ARDL approach. When life expectancy was used as proxy, a positive impact on poverty reduction was revealed in the short run. In the same vein, Soumare (2015) in a study on Northern African countries, found a positive association between poverty reduction and FDI. Fauzel, Seetanah and Sannassee (2015) found the same results in a study on subSaharan African countries using data from 1990 to 2010, poverty headcount as a poverty proxy, and panel vector error correction approach.

Gohou and Soumare (2012), in a study on Central and East African countries, employed HDI and GDP per capita as proxies for poverty and found FDI to have a negative impact on poverty. Shamim, Azeem and Naqvi (2014) found the same results in a study on Pakistan using poverty headcount as a proxy for poverty. Fowowe and Shuaibu (2014), in a study of 30 African countries, using poverty headcount as a proxy for poverty, found the same results as Gohou and Soumare (2012). In the same spirit, Ucal (2014) found FDI to reduce poverty in a study on 26 developing countries using unbalanced panel analysis with data spanning from 1990 to 2009. Although FDI was found to have a poverty mitigating effect, another relook into the relationship remains important because of the time lag from the time these studies were done; the poverty measures used and the sample size.

The second group of studies found FDI to worsen poverty. Anetor et al., (2020) investigated the impact of FDI, trade and foreign aid on poverty in 29 sub-Saharan African countries using Feasible Generalised Least Squares (FGLS). In the study, FDI was found to have negative effects on poverty reduction. Magombeyi and Odhiambo (2018b) found the same results as Anetor et al. (2020) in a study on Botswana. Employing ARDL approach, FDI was found to worsen poverty when life expectancy was used as a poverty reduction proxy in the long-run. The same study also found a negative impact of FDI on poverty reduction when household consumption expenditure was used as a measure of poverty, in the short run. The same findings were obtained in separate studies by Huang et al. (2010) in East Asia and Latin America and Ali, Nishat and Anwar (2010) in a study on Pakistan.

The third group of studies found FDI to have an insignificant impact on poverty. Magombeyi and Odhiambo (2018b) in a study on the impact of FDI on poverty reduction in Botswana using household consumption expenditure as a proxy, found an insignificant impact in the long run. The same study also found insignificant relationship between poverty and FDI when infant mortality rate was used as a proxy. In the same vein, Gohou and Soumare (2012) found FDI to have an insignificant impact on poverty in Southern and Northern regions in Africa.

The findings from studies reviewed show a variation depending on the study period, poverty proxy used, methodology employed and the study area under 
consideration. Given the dynamic changes that take place in the economic, social, and political spaces, another study on the impact of foreign capital inflows on poverty will inform policy in Vietnam on its poverty reduction journey, in general, and among the country's ethnic minorities, in particular.

\section{Estimation techniques ARDL approach to cointegration}

In this study the ARDL bounds testing approach is used because of a number of advantages it has. The ARDL-bounds approach is based on a joint F-statistic with a non-standard distribution (Pesaran et al., 2001). The ARDL approach to cointegration involves an OLS estimation of the ARDL model to establish long-run relationship. This stage involves construction of the unrestricted error correction model and the testing of the lagged level variables for a long-run relationship (see Pesaran et al. 2001). The ARDL model based on two sets of critical values, an upper bound and a lower bound. If the calculated F-statistic is above the upper bound critical value, the null hypothesis of no long-run relationship is rejected and cointegration is confirmed, while in the case of the F-statistic falling below the lower bound, the hull hypotheses of no cointegration cannot be rejected (Pesaran et al., 2001). When the calculated F-statistic falls between the lower and the upper bound, the results are inconclusive (Pesaran et al., 2001). The critical values provided by Pesaran el al. (2001) are suitable for samples between 500 and 1000 and 20000 to 40000 replications (Narayan, 2005). Given the small sample in this study, critical values developed by Narayan (2005) are used for a sample of 30. The critical values are also reported in Table 2. The advantages of the ARDL approach include: robustness in small samples; the approach uses a single reduced form equation compared to some approaches that use a system of equation like the Johansen and Juselius (1990); the ARDL approach does not require all variables to be integrated on the same order, a combination of variables integrated of order 0 [I (0)], order one [I(1)] or fractionally integrated can be used (Pesaran, Shin and Smith, 2001).

\section{Variable description}

The main variables of interest in this study are foreign capital inflows and poverty. Three poverty proxies namely, infant mortality rate, household consumption expenditure and human development index are used in this study. Infant mortality rate is measured by the number of infant deaths per 1000 births; human development index is a composite measure of living standard, life expectancy and schooling; and household consumption expenditure is expressed as a percentage of GDP. Foreign capital flows are measured by foreign direct investment (FDI) as a percentage of GDP and external debt (EXD) as a percentage of gross national income. The impact of FDI on poverty is expected to vary depending on the measure of poverty used. While the impact is anticipated to be negative when poverty is proxied infant mortality rate, it is expected to be positive when poverty is measured in terms of $\mathrm{HDI}$ and household consumption expenditure. In the same vein, external debt is expected to have a negative impact on HDI and household consumption expenditure but a positive impact on infant mortality rate.

Other control variables included in the study are: i) trade balance as a percentage of GDP (TR); which captures the trade volume of a country with external parties. A positive relationship is expected between trade balance and poverty measured by $\mathrm{HDI}$ and household consumption expenditure and a negative 
relationship when poverty is measured by infant mortality rate; ii) economic growth (GDPR), proxied by real GDP growth rate, which captures standards of living. A positive impact is expected when poverty is measured by HDI and household consumption expenditure, and a negative impact is anticipated when poverty is measured by infant mortality rate; iii) education (EDU), captured by gross primary school enrolment. Education is expected to reduce poverty; and iv) price level (INFL) measured by GDP deflator. Price level is expected to worsen poverty levels.

\section{Models}

This study employs two (2) models to investigate the impact of foreign capital inflows on poverty in Vietnam. Model 1 investigates the impact of FDI on poverty when poverty is measured by human development index (HDI), household consumption expenditure (HCE) and infant mortality rate (INFA) respectively, whilst holding the control variables the same. Model 2 captures the impact of external debt on poverty when poverty is measured by HDI, HCE and INFA respectively, whilst keeping control variables the same. The ARDL model specification are given in Equations 1 and 2.

ARDL General Model Specification:

$$
\begin{aligned}
& \Delta \mathrm{P}_{\mathrm{nt}}=\vartheta_{0}+\sum_{\mathrm{i}=1}^{\mathrm{n}} \vartheta_{1 \mathrm{i}} \Delta \mathrm{P}_{\mathrm{nt}-\mathrm{i}}+\sum_{\mathrm{i}=0}^{\mathrm{n}} \vartheta_{2 \mathrm{i}} \Delta \mathrm{FDI}_{\mathrm{t}-\mathrm{i}}+\sum_{\mathrm{i}=0}^{\mathrm{n}} \vartheta_{3 \mathrm{i}} \Delta \mathrm{GDPR}_{\mathrm{t}-\mathrm{i}}+\sum_{\mathrm{i}=0}^{\mathrm{n}} \vartheta_{4 \mathrm{i}} \Delta \mathrm{TRD}_{\mathrm{t}-\mathrm{i}} \\
& +\sum_{\mathrm{i}=0}^{\mathrm{n}} \vartheta_{5 \mathrm{i}} \Delta \mathrm{EDU}_{\mathrm{t}-\mathrm{i}}+\sum_{\mathrm{i}=0}^{\mathrm{n}} \vartheta_{6 \mathrm{i}} \Delta \mathrm{INFL}_{\mathrm{t}-\mathrm{i}}+\vartheta_{7} \mathrm{P}_{\mathrm{nt}-1}+\vartheta_{8} \mathrm{FDI}_{\mathrm{t}-1}+\vartheta_{9} \mathrm{GDPR}_{\mathrm{t}-1} \\
& +\vartheta_{10} \mathrm{TRD}_{\mathrm{t}-1}+\vartheta_{11} \mathrm{EDU}_{\mathrm{t}-1}+\vartheta_{12} \mathrm{INFL}_{\mathrm{t}-1}+\mu_{1 \mathrm{t}} \\
& \Delta \mathrm{P}_{\mathrm{nt}}=\beta_{0}+\sum_{\mathrm{i}=1}^{\mathrm{n}} \beta_{1 \mathrm{i}} \Delta \mathrm{P}_{\mathrm{nt}-\mathrm{i}}+\sum_{\mathrm{i}=0}^{\mathrm{n}} \beta_{2 \mathrm{i}} \Delta \mathrm{EXD}_{\mathrm{t}-\mathrm{i}}+\sum_{\mathrm{i}=0}^{\mathrm{n}} \beta_{3 \mathrm{i}} \Delta \mathrm{GDPR}_{\mathrm{t}-\mathrm{i}}+\sum_{\mathrm{i}=0}^{\mathrm{n}} \beta_{4 \mathrm{i}} \Delta \mathrm{TRP}_{\mathrm{t}-\mathrm{i}} \\
& +\sum_{\mathrm{i}=0}^{\mathrm{n}} \beta_{5 \mathrm{i}} \Delta \mathrm{EDU}_{\mathrm{t}-\mathrm{i}}+\sum_{\mathrm{i}=0}^{\mathrm{n}} \beta_{6 \mathrm{i}} \Delta \mathrm{INFL}_{\mathrm{t}-\mathrm{i}}+\beta_{7} \mathrm{P}_{\mathrm{nt}-1}+\beta_{8} \mathrm{FDI}_{\mathrm{t}-1}+\beta_{9} \mathrm{GDPR}_{\mathrm{t}-1} \\
& +\beta_{10} \text { TRD }_{\mathrm{t}-1}+\beta_{11} \mathrm{EDU}_{\mathrm{t}-1}+\beta_{12} \text { INFL }_{\mathrm{t}-1}+\mu_{2 \mathrm{t}}
\end{aligned}
$$

where $P_{n}$ is poverty and takes the value of HDI - Human Development Index, HCE household consumption expenditure and INFA - infant rate in each of the equations where foreign direct investment (FDI) and external debt (EXD) are key explanatory variables, whilst the control variables remain the same. The control variables are GDPR-real Gross Domestic Product, TRD-trade balance, EDU-education, and INFLinflation. $\vartheta_{0}$ and $-\beta_{0}$ are constants, $\vartheta_{1}-\vartheta_{5}$ and $\beta_{1}-\beta_{5}$ are coefficients and $\varepsilon$ is the error term.

The error correction specification of Equations 1 and 2 are given in Equation 3 and 4, respectively:

$$
\begin{gathered}
\Delta \mathrm{P}_{\mathrm{nt}}=\vartheta_{0}+\sum_{\mathrm{i}=1}^{\mathrm{n}} \vartheta_{1 \mathrm{i}} \Delta \mathrm{P}_{\mathrm{nt}-\mathrm{i}}+\sum_{\mathrm{i}=0}^{\mathrm{n}} \vartheta_{2 \mathrm{i}} \Delta \mathrm{FDI}_{\mathrm{t}-\mathrm{i}}+\sum_{\mathrm{i}=0}^{\mathrm{n}} \vartheta_{3 \mathrm{i}} \Delta \mathrm{GDPR}_{\mathrm{t}-\mathrm{i}}+\sum_{\mathrm{i}=0}^{\mathrm{n}} \vartheta_{4 \mathrm{i}} \Delta \mathrm{TRD}_{\mathrm{t}-\mathrm{i}} \\
+\sum_{\mathrm{i}=\mathrm{o}}^{\mathrm{n}} \vartheta_{5 \mathrm{i}} \Delta \mathrm{EDU}_{\mathrm{i}-1}+\sum_{\mathrm{i}=\mathrm{o}}^{\mathrm{n}} \vartheta_{6 \mathrm{i}} \Delta \mathrm{PNFL}_{\mathrm{t}-\mathrm{i}}+\mathrm{y}_{1} \mathrm{ECM}_{\mathrm{t}-1}+\mu_{1 \mathrm{t}}
\end{gathered}
$$




$$
\begin{aligned}
\mathrm{P}_{\mathrm{nt}}=\beta_{0}+\sum_{\mathrm{i}=1}^{\mathrm{n}} \beta_{1 \mathrm{i}} \Delta \mathrm{P}_{\mathrm{nt}-\mathrm{i}}+\sum_{\mathrm{i}=0}^{\mathrm{n}} \beta_{2 \mathrm{i}} \Delta \mathrm{EXD}_{\mathrm{t}-\mathrm{i}}+\sum_{\mathrm{i}=0}^{\mathrm{n}} \beta_{3 \mathrm{i}} \Delta \mathrm{GDPR}_{\mathrm{t}-\mathrm{i}}+\sum_{\mathrm{i}=0}^{\mathrm{n}} \beta_{4 \mathrm{i}} \Delta \mathrm{TRD}_{\mathrm{t}-\mathrm{i}} \\
+\sum_{\mathrm{i}=\mathrm{o}}^{\mathrm{n}} \beta_{5 \mathrm{i}} \Delta \mathrm{EDU}_{\mathrm{i}-1}+\sum_{\mathrm{i}=\mathrm{o}}^{\mathrm{n}} \beta_{6 \mathrm{i}} \Delta \mathrm{PNFL}_{\mathrm{t}-\mathrm{i}}+\mathrm{y}_{2} \mathrm{ECM}_{\mathrm{t}-1}+\mu_{2 \mathrm{t}}
\end{aligned}
$$

where $\vartheta_{1 i}-\vartheta_{6 i}$ and $y_{1}$ and $y_{2}$ are coefficients, $E C M_{t-1}$ is lagged error correction term, $\mu_{t}$ is white noise error term and the rest of the variables are as defined in Equations 1 and 2 .

\section{Data Sources}

Annual time series data from 1990 to 2018 was used to investigate the impact of foreign capital inflows on poverty in Vietnam. Infant mortality rate (INFA), trade balance (TRD), GDP growth rate (GDPR), foreign direct investment (FDI), external debt (EXD) and gross primary school enrolment (EDU) data was extracted form World Bank Development Indicators (World Bank, 2020). Human Development Index data was obtained from United Nations Development Programme (UNDP, 2020). Microfit 5.0 was used for data analysis.

\section{Results}

\section{Unit Root Test}

Although the ARDL bounds testing approach does not require pretesting of variables for stationarity, unit root tests were done to ascertain that the variables included in the models are not integrated of an order greater than one - as the approach falls away with variables integrated of an order greater than 1. Two-unit root tests were used in this study, namely, Dickey Fuller Generalised Least Squares (DF-GLS) and Phillips Perron (PP). The results of the unit root tests are reported in Table 1.

\begin{tabular}{|c|c|c|c|c|c|c|c|c|}
\hline \multicolumn{5}{|c|}{ ADF-GLS Test } & \multicolumn{4}{|l|}{ PP Test } \\
\hline \multirow[t]{2}{*}{ Variable } & \multicolumn{2}{|c|}{$\begin{array}{l}\text { Stationarity of Variable } \\
\text { in Levels }\end{array}$} & \multicolumn{2}{|c|}{$\begin{array}{lll}\text { Stationarity } & & \text { of } \\
\text { Variable } & \text { in } & \text { First } \\
\text { Difference } & & \end{array}$} & \multicolumn{2}{|c|}{$\begin{array}{ll}\text { Stationarity } & \text { of } \\
\text { Variable in Levels }\end{array}$} & \multicolumn{2}{|c|}{$\begin{array}{l}\text { Stationarity } \\
\text { Variable in } \\
\text { Difference }\end{array}$} \\
\hline & $\begin{array}{l}\text { Without } \\
\text { Trend }\end{array}$ & $\begin{array}{l}\text { With } \\
\text { Trend }\end{array}$ & $\begin{array}{l}\text { Without } \\
\text { Trend }\end{array}$ & $\begin{array}{l}\text { With } \\
\text { Trend }\end{array}$ & $\begin{array}{l}\text { Without } \\
\text { Trend }\end{array}$ & $\begin{array}{l}\text { With } \\
\text { Trend }\end{array}$ & $\begin{array}{l}\text { Without } \\
\text { Trend }\end{array}$ & $\begin{array}{l}\text { With } \\
\text { Trend }\end{array}$ \\
\hline HDI & -0.4063 & -0.7599 & $-2.4124^{* *}$ & $-6.7889 * * *$ & -1.6107 & -3.0173 & $-8.6046^{* * *}$ & $-8.7079 * * *$ \\
\hline INFA & -0.9425 & -0.8598 & $-2.3661^{*}$ & $-2.9121^{*}$ & -1.1947 & -1.7316 & $-8.8084^{* * *}$ & $-5.9200 * *$ \\
\hline $\mathrm{HCE}$ & -1.3139 & -1.5878 & $-3.5224^{* * *}$ & $-4.6460 * * *$ & -1.7032 & -2.2657 & $-3.9566^{* *}$ & $-4.4938^{* * *}$ \\
\hline FDI & $-2.2887^{* *}$ & $-2.5286^{* * *}$ & - & $-4.9438^{* * *}$ & $-2.6760^{*}$ & -2.6092 & - & $-4.7709^{* * *}$ \\
\hline EXD & $-4.1328^{* * *}$ & $-5.8740 * * *$ & - & - & $-4.2533^{* * *}$ & $-5.979 * * *$ & - & - \\
\hline GDPR & $-2.1991^{* *}$ & $-3.0216^{* *}$ & - & - & $-2.6753^{*}$ & $-3.0541^{*}$ & - & - \\
\hline TRD & -0.8685 & $-3.8213^{* *}$ & $-2.5727^{* *}$ & - & $-6.7717^{* * *}$ & $-6.7829 * * *$ & - & - \\
\hline EDU & $-3.8271^{* * *}$ & $-3.8573^{* * *}$ & - & - & -1.6219 & -1.6271 & $-2.8855^{*}$ & $-3.5676^{*}$ \\
\hline $\mathrm{PL}$ & -0.6629 & -1.46885 & $-1.9792^{* *}$ & $-5.8907^{* * *}$ & $-7.5940^{* * *}$ & $-8.7394^{* * *}$ & - & - \\
\hline
\end{tabular}

Table 1 Unit root test results

Note: ${ }^{*}, * *$ and ${ }^{* * *}$ denote stationarity at $10 \%, 5 \%$ and $1 \%$ significance levels respectively.

The unit root results presented in Table 1 reveal that all variables are stationary in their levels or in first difference. The results give a green light to proceed with the ARDL approach on the analysis of the impact of foreign capital inflows on poverty in Vietnam. To proceed with the analysis, the next step is to test for cointegration. The cointegration results are specified in Table 2. 


\section{ARDL bound test to cointegration}

The results of the bounds test for cointegration for Function 1-6 are presented in Table 2.

Table 2 Cointegration results and critical values

\begin{tabular}{|c|c|c|c|c|}
\hline CIF proxy & $\begin{array}{l}\text { Independent } \\
\text { Variables }\end{array}$ & Function & F-statistic & $\begin{array}{l}\text { Cointegration } \\
\text { Status }\end{array}$ \\
\hline \multirow{3}{*}{$\begin{array}{l}\text { Foreign } \\
\text { Direct } \\
\text { Investment } \\
\text { (FDI) }\end{array}$} & $\mathrm{HDI}$ & F (HDI | FDI, GDPR, EDU, TRD, INFL) & $5.2714^{* *}$ & Cointegrated \\
\hline & $\mathrm{HCE}$ & F (FDI | GDPR, EDU, TRD, INFL & $3.9478^{*}$ & Cointegrated \\
\hline & INFA & F (FDI | GDPR, EDU, TRD, INFL & $5.7988^{* *}$ & Cointegrated \\
\hline \multirow{3}{*}{$\begin{array}{l}\text { External } \\
\text { Debt } \\
\text { (EXD) }\end{array}$} & $\mathrm{HDI}$ & F (EXD | GDPR, EDU, TRD, INFL & $4.1853^{*}$ & Cointegrated \\
\hline & $\mathrm{HCE}$ & $\mathrm{F}(\mathrm{EXD} \mid \mathrm{GDPR}, \mathrm{EDU}, \mathrm{TRD}, \mathrm{INFL})$ & $4.9893^{* *}$ & Cointegrated \\
\hline & INFA & $\mathrm{F}$ (EXD | GDPR, EDU, TRD, INFL) & $4.6138^{* *}$ & Cointegrated \\
\hline
\end{tabular}

Asymptotic Critical Values (unrestricted intercept and no trend)

\begin{tabular}{|c|c|c|c|c|c|c|}
\hline \multirow{3}{*}{$\begin{array}{l}\text { Pesaran et al. }(2001: 300) \\
\text { critical values (Table } \mathrm{Cl} \text { (iii) } \\
\text { Case III) }\end{array}$} & \multicolumn{2}{|l|}{$10 \%$} & \multicolumn{2}{|l|}{$5 \%$} & \multicolumn{2}{|l|}{$1 \%$} \\
\hline & I (0) & I (1) & I (0) & I(1) & I (0) & I(1) \\
\hline & 2.26 & 3.35 & 2.62 & 3.79 & 3.41 & 4.68 \\
\hline Narayan (2005) critical vales & 2.58 & 3.86 & 3.13 & 4.61 & 4.54 & 6.37 \\
\hline
\end{tabular}

Note: ${ }^{*}, * *$ and ${ }^{* * *}$ denote statistical significance at $10 \%, 5 \%$ and $1 \%$ levels respectively.

The F-statistic for each function is compared to the critical values, also provided in the table. If the F-statistic is greater than the I (1) bound at $1 \%, 5 \%$ or $10 \%$ significance level, cointegration is confirmed. However, if the F-statistics is less than I (0) bound, no cointegration is confirmed. The results of the cointegration test, using the critical values by Narayan (2005), displayed in Table 2, confirm the presence of cointegration across all the functions, implying the presence of a long-run relationship among the variables in each function.

\section{Coefficient estimation}

Confirmation of cointegration in the six functions, as specified in Table 2, implies that the study proceeds to the estimation of coefficients - both long-run and short-run coefficients. This is done using the ARDL procedure. Selection of optimal lags for variables in the equations was done using the Schwarz Bayesian Information Criteria $(\mathrm{SIC})$ or the Akaike Information Criteria (AIC), depending on the approach that gives the most parsimonious result. The optimal lag length selected for Functionl is ARDL $(2,2,1,0,0,1)$, based on SIC; for Function 2, it is ARDL $(1,0,0,0,0,1)$, based on AIC; for Function 3, it is ARDL $(1,0,2,0,0,0)$, based on SBC; for Function 4, it is ARDL $(1,2$, $1,0,2,2)$, based on AIC; for Function 5, ARDL $(1,0,2,0,0,2)$, based on SIC; and for Function 6 , ARDL $(1,2,0,1,2,1)$, based on SIC. The long-run and short-run coefficients for Functions $1-3$ are reported in Tables 3 and 4 , while Tables 5 and 6 show long-run and short-run coefficients for Function 4-6.

Table 3 and Table 4 report long-run and short-run results, respectively when poverty is measured by HDI, household consumption expenditure (HCE) and infant mortality rate (INFA) with FDI being the variable of interest. The results show that FDI has a positive impact on poverty - FDI leads to poverty reduction - both in the long run and in the short run when household consumption expenditure is used as a proxy. This is shown by a statistically significant coefficient at $5 \%$ and $10 \%$ level of significance in the long run and short run, respectively. Magombeyi and Odhiambo (2018a) in a study on South Africa and Fauzel et al. (2015) in a separate study on sub- 
Saharan African countries found the same results. Past HDI was also found to have a significant impact on current HDI. Thus, past poverty reduction measures have an important impact on the current poverty reduction efforts. This implies that Vietnam policy makers should press on with poverty alleviation policies and benefit from the dividend of past effort.

Table 3 Long-run results when FDI is used as a key independent variable

\begin{tabular}{|l|l|l|l|l|l|l|}
\hline Variables & \multicolumn{2}{l}{$\begin{array}{l}\text { Function 1: Dependent } \\
\text { variable HDI ARDL }(2,2,1,\end{array}$} \\
& $\begin{array}{l}\text { Function 2: Dependent } \\
\text { variable HCE } \\
\text { ARDL (1, 0, 0, 0, 0, 1) }\end{array}$ & \multicolumn{2}{l|}{$\begin{array}{l}\text { Function 3: Dependent } \\
\text { variable INFA } \\
\text { ARDL (1, 0, 2, 0, 0, 0) }\end{array}$} \\
\hline Regressors & Coefficient & T-ratio & Coefficient & T-ratio & Coefficient & T-ratio \\
\hline C & $0.9565^{* * *}$ & 5.8637 & $64.3467^{*}$ & 1.9163 & $65.0178^{* * *}$ & 5.5420 \\
\hline FDI & 0.0062 & 1.9030 & $0.4100^{* *}$ & 2.7785 & $0.4722^{* * *}$ & 3.3650 \\
\hline GDPR & $0.0109^{*}$ & 1.8481 & $0.3640^{*}$ & 1.8478 & $-0.8630^{* *}$ & -2.1501 \\
\hline TRD & 0.4524 & 1.2151 & 0.0679 & 0.4793 & $-0.0859^{* * *}$ & -4.1510 \\
\hline EDU & $-0.0030^{* *}$ & -2.5081 & $-0.2045^{*}$ & -1.8398 & $-0.4318^{* * *}$ & 3.4505 \\
\hline PL & 0.3248 & 0.9455 & -0.0241 & -0.2480 & $0.0965^{* * *}$ & -3.8772 \\
\hline
\end{tabular}

Note: ${ }^{*},{ }^{* *}$ and ${ }^{* * *}$ denote stationarity at $10 \%, 5 \%$ and $1 \%$ significance levels, respectively.

Table 4 Short-run results when FDI is a key explanatory variable

\begin{tabular}{|c|c|c|c|c|c|c|}
\hline \multirow{2}{*}{$\begin{array}{l}\text { Variables } \\
\text { Regressors } \\
\end{array}$} & \multicolumn{2}{|c|}{$\begin{array}{l}\text { Function 1: Dependent } \\
\text { variable HDI } \\
\text { ARDL }(2,2,1,0,0,1)\end{array}$} & \multicolumn{2}{|c|}{$\begin{array}{l}\text { Function 2: Dependent } \\
\text { variable HCE } \\
\text { ARDL }(1,0,0,0,0,1)\end{array}$} & \multicolumn{2}{|c|}{$\begin{array}{l}\text { Function 3: Dependent } \\
\text { variable INFA } \\
\text { ARDL }(1,0,2,0,0,0)\end{array}$} \\
\hline & Coefficient & T-ratio & Coefficient & T-ratio & Coefficient & T-ratio \\
\hline $\mathrm{dHDI}$ & $0.5963^{* * *}$ & -3.3636 & - & - & - & - \\
\hline dFDI & $-0.1449 * *$ & 2.5218 & $0.3329 *$ & 2.0952 & $0.0297^{* * *}$ & 3.5400 \\
\hline dFDIl & -0.7002 & -1.5556 & - & - & - & - \\
\hline dGDPR & -0.0012 & -1.5711 & $0.3220^{*}$ & 1.9750 & -0.0167 & -0.8510 \\
\hline dGDPR 1 & - & - & - & - & $0.0310 *$ & 1.7642 \\
\hline dTRD & 0.7701 & 0.8908 & 0.0160 & 0.5440 & $-0.0054^{* *}$ & -3.2316 \\
\hline dEDU & $-0.5169^{*}$ & -1.7822 & $-0.0482^{*}$ & -1.7982 & $-0.02724^{* * *}$ & -6.2075 \\
\hline $\mathrm{dPL}$ & 0.4832 & 0.0335 & -0.0277 & -0.4253 & $0.0061^{* * *}$ & 5.5698 \\
\hline \multirow[t]{2}{*}{$\operatorname{dECM}(-1)$} & $-0.1702^{*}$ & -1.8998 & $-0.23606^{* *}$ & -2.1787 & $-0.0631^{* * *}$ & -5.0086 \\
\hline & \multicolumn{2}{|c|}{$\begin{array}{l}\text { R-squared }-0.712 \\
\text { R-Bar squared }-0.651 \\
\text { S.E. of regression }-0.002 \\
\text { AIC }-114.806 \\
\text { SBC }-107.031 \\
\text { DW }-2.171 \\
\text { Residual sum of squares } \\
-0.132\end{array}$} & \multicolumn{2}{|c|}{$\begin{array}{l}\text { R-squared }-0.7392 \\
\text { R-bar squared }-0.6195 \\
\text { S.E. of regression }-1.3763 \\
\text { AIC }--50.1952 \\
\text { SBC }--55.3786 \\
\text { DW }-1.9958 \\
\text { Residual sum of squares - } \\
36.0005\end{array}$} & \multicolumn{2}{|c|}{$\begin{array}{l}\text { R-squared }-0.988 \\
\text { R-bar squared }-0.982 \\
\text { S.E. of regression }-0.067 \\
\text { AIC }-31.174 \\
\text { SBC }-25.343 \\
\text { DW }-1.7801 \\
\text { Residual sum of squares } \\
-0.081\end{array}$} \\
\hline
\end{tabular}

Notes: ${ }^{*},{ }^{* *}$ and ${ }^{* * *}$ denotes stationarity at $10 \%, 5 \%$ and $1 \%$ significance levels respectively.

Further analysis of results reveals that FDI worsens poverty in the short run when HDI was used as a proxy and in both the long run and the short run when infant mortality rate was used as a proxy. A possible explanation for this result could be the stiff competition brought by FDI companies that causes a scale down or closure of domestic companies. Those results in loss of jobs and the poor are trapped in unemployment as they do not possess skills required by the new competitors. Other studies that found the same results are Anetor et al., (2020) and Magombeyi and Odhiambo (2018b). 
Other results presented in Table 3 and Table 4 shows that GDP growth rate (GDPR) mitigates poverty in the long run when HDI is used as a proxy; GDPR reduces poverty in both the short run and the long run when household consumption is used as a proxy; and in the long run when infant mortality rate is used as a proxy. This finding points to the importance of economic growth in increasing the level of income in an economy, which consequently, increase economic activities, household income and affordability of basic services like education and health. Thus, Vietnam is encouraged to continue supporting economic growth policies in order to benefit in the poverty reduction agenda. Trade balance was found to reduce poverty in the long run and in the short run when infant mortality rate was used a proxy, while an insignificant impact in the long run and in the short run was found when HDI and household consumption expenditure were used as proxies. The results suggest that trade balance negatively affect income poverty. Education (EDU) was found to reduce poverty when infant mortality rate was used as a proxy for poverty. This finding suggests the importance of education in enhancing the ability of the poor to understand and undertake preventive health measures. Education was found to increase poverty when HDI and household consumption expenditure were used as proxies. These two proxies are more inclined to measuring household affordability, however, the negative impact could be monetary demands of sending children to school. This reduces household welfare in the short run and even in the long run if the children remain unemployed. Price level (PL) was found to have a negative impact on poverty when infant mortality rate was used as a measure of poverty in the long run and in the short run. According to Mohr (2015), there is a level of general price increase that ensures that producers in the economy are stimulated to produce more. This ideal price change, according to this study, ensures that health service provision is sufficient to meet household needs. However, price level was found to have insignificant impact on poverty when $\mathrm{HDI}$ and household consumption expenditure were used as proxies.

Table 5 and Table 6 report short run and long run results when external debt (EXD) is the main explanatory variable in the three functions, where poverty is measured by $\mathrm{HDI}$, household consumption expenditure and infant mortality rate. The results reported in Table 5 - long-run results, and Table 6 - short-run results, show that external debt has a positive and significant impact on poverty, both in the long run and in the short run when poverty is measured by household consumption expenditure. These findings point to the poverty mitigating effect of external debt. These results are contrary to expectations and findings from other studies (see, Oyedele et al., 2013; Loko et al., 2003). This can be explained by external debt being a source of economic development funding, allowing the Vietnam government to support economic development and poverty alleviation programmes at a level that could not be attained when using internal resources. Thus, making the benefits of external debt higher than the cost associated with the burden of repayment. However, using the same poverty proxy, past household expenditure was found to alleviate current poverty. When HDI was used as a proxy for poverty, external debt was found to have an insignificant impact on poverty in the long run and a positive impact in the short run. When infant mortality rate was used as a proxy for poverty, external debt was found to reduce poverty in the long run and increase poverty in the short run. Thus, external debt reduces poverty in the short term and worsens poverty in the long run, according to the findings of this study. The results across all poverty proxies show a consistent poverty mitigating effect of external debt in the short run, irrespective of the poverty proxy used. 
Table 5 Long-run results when external debt is a key independent variable

\begin{tabular}{|l|l|l|l|l|l|l|}
\hline Variables & \multicolumn{2}{l}{$\begin{array}{l}\text { Function 4: Dependent } \\
\text { variable HDI } \\
\text { ARDL }(1,2,1,0,2,2)\end{array}$} & \multicolumn{2}{l|}{$\begin{array}{l}\text { Function 5: Dependent } \\
\text { variable HCE } \\
\text { ARDL }(1,0,2,0,0,2)\end{array}$} & \multicolumn{2}{l|}{$\begin{array}{l}\text { Function 6: Dependent } \\
\text { variable INFA } \\
\text { ARDL }(1,2,0,1,2,1)\end{array}$} \\
\hline Regressors & Coefficient & T-ratio & Coefficient & T-ratio & Coefficient & T-ratio \\
\hline C & $0.8240^{* * *}$ & 10.4508 & $35.4277^{* * *}$ & 3.323 & $-29.4479^{* * *}$ & 4.8551 \\
\hline EXD & -0.3426 & -0.2467 & $0.0653^{* * *}$ & 6.3810 & $0.02276^{* * *}$ & 4.4491 \\
\hline GDPR & $-0.0087^{* *}$ & -2.1610 & 0.2241 & 0.6031 & $-0.0801^{* * *}$ & -0.7027 \\
\hline TRD & $0.7188^{* *}$ & 2.4442 & $0.0744^{*}$ & 1.9422 & $-0.0389^{* * *}$ & -4.4617 \\
\hline EDU & $-0.0021^{* * *}$ & -4.0311 & $0.2081^{* *}$ & 2.4914 & -0.0661 & -1.1205 \\
\hline PL & 0.1114 & 0.2950 & $-0.0651^{* *}$ & -2.3258 & -0.0036 & -0.2833 \\
\hline
\end{tabular}

Note: ${ }^{*},{ }^{* *}$ and ${ }^{* * *}$ denote stationarity at $10 \%, 5 \%$ and $1 \%$ significance levels, respectively.

Table 6 Short- run results when external debt is a key explanatory variable

\begin{tabular}{|c|c|c|c|c|c|c|}
\hline \multirow{2}{*}{$\begin{array}{l}\text { Variables } \\
\text { Regressors } \\
\end{array}$} & \multicolumn{2}{|c|}{$\begin{array}{l}\text { Function 4: Dependent } \\
\text { variable HDI } \\
\text { ARDL }(1,2,1,0,2,2)\end{array}$} & \multicolumn{2}{|c|}{$\begin{array}{l}\text { Function 5: Dependent } \\
\text { variable HCE } \\
\text { ARDL }(1,0,2,0,0,2)\end{array}$} & \multicolumn{2}{|c|}{$\begin{array}{l}\text { Function 6: Dependent } \\
\text { variable INFA } \\
\text { ARDL }(1,2,0,1,2,1)\end{array}$} \\
\hline & Coefficient & T-ratio & Coefficient & T-ratio & Coefficient & T-ratio \\
\hline $\mathrm{dHDI}$ & $-0.7473^{* * *}$ & & - & - & 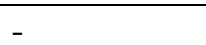 & - \\
\hline $\mathrm{dHECl}$ & - & - & $0.4658^{* *}$ & 2.1582 & - & - \\
\hline dEXD & $0.1773^{* *}$ & 2.4890 & $0.0546^{* * *}$ & & & -0.7240 \\
\hline dEXDI & - & - & - & - & $-0.0030 * * *$ & -3.6894 \\
\hline dGDPR & -0.8810 & -0.0138 & 0.1875 & 0.6283 & -0.01423 & 0.8089 \\
\hline dGDPR 1 & $0.0020 * * *$ & 2.8228 & - & - & - & - \\
\hline dTRD & $0.2605^{* * *}$ & 3.1057 & $0.0623^{*}$ & 2.0511 & $-0.0043^{* *}$ & -2.3326 \\
\hline dEDU & $-0.0016^{* * *}$ & -2.9829 & $0.4045^{*}$ & 1.9967 & -0.0086 & 0.9346 \\
\hline dEDU1 & 0.2331 & -0.5985 & - & - & $0.0224^{* *}$ & 2.6178 \\
\hline dEDU2 & $-0.0026^{* * *}$ & & - & - & & - \\
\hline $\mathrm{dPL}$ & 0.4036 & 0.2 & 0.00 & 0.0887 & & -1.3801 \\
\hline \multirow[t]{2}{*}{$\operatorname{ECM}(-1)$} & -0.3623 & -1.9761 & $-0.8370 * * *$ & -3.6305 & $-0.1772^{* * *}$ & -3.9912 \\
\hline & \multicolumn{2}{|c|}{$\begin{array}{l}\text { R-squared }-0.87 \\
\text { R-bar squared }-0.729 \\
\text { S.E of regression }-0.0021 \\
\text { AIC }-118.498 \\
\text { SBC }-109.891 \\
\text { DW }-2.184 \\
\text { Residual Sum of Squares } \\
-0.570\end{array}$} & \multicolumn{2}{|c|}{$\begin{array}{l}\text { R-squared }-0.640 \\
\text { R-bar squared }-0.449 \\
\text { S.E of regression }-1.290 \\
\text { AIC }--48.879 \\
\text { SBC }--55.3584 \\
\text { DW }-2.360 \\
\text { Residual Sum of Squares } \\
-28.1600\end{array}$} & \multicolumn{2}{|c|}{$\begin{array}{l}\text { R-squared }-0.995 \\
\text { R-bar Squared }-0.991 \\
\text { S.E of Regression }-0.0474 \\
\text { AIC }-39.8723 \\
\text { SBC }-31.4493 \\
\text { DW }-2.2368 \\
\text { Residual sum of squares } \\
-0.0315\end{array}$} \\
\hline
\end{tabular}

Note: ${ }^{*},{ }^{* *}$ and ${ }^{* * *}$ denote stationarity at $10 \%, 5 \%$ and $1 \%$ significance levels, respectively.

Other results presented in Table 5 and Table 6 confirm that GDPR reduces poverty in the short run, but increases poverty in the long run when HDI is used as poverty proxy. However, when infant mortality rate is used as a proxy, GDPR reduces poverty in the long run. GDPR was found to have an insignificant impact in the long run and in the short run when household consumption expenditure was used as a proxy for poverty. Trade balance has a positive impact on poverty in the short run and the long run when poverty is proxied by HDI and household consumption expenditure. When infant mortality rate is used as a proxy, a negative relationship was registered in both the long run and the short run, indicating poverty alleviating effect of trade balance. Hence, across all poverty proxies, trade balance was confirmed to have 
poverty mitigating effect irrespective of the period considered. Thus, the Vietnam's government policy to advance international relations would also work towards poverty reduction, among other policy initiatives.

Education increases poverty in the long run and the short run when HDI was used as a proxy. When infant mortality rate was used as a proxy for poverty, education was found to have an insignificant impact on poverty in the long but a poverty alleviating effect in the short run. However, when poverty is measured by household consumption expenditure, education was found to mitigate poverty in the long run and in the short run. The price level was found to have an insignificant impact in the long run and increases poverty in the short run when household consumption expenditure was used as a proxy. Thus, high prices erode the purchasing power of the households in the short run, worsening poverty (Mohr and Associates, 2015). However, when poverty was proxied by infant mortality rate and household consumption expenditure, price level was found to be insignificant, regardless of the period considered. A summary of the results is reported in Table 7.

Table 7 A summary of the findings

\begin{tabular}{|l|l|l|l|l|l|}
\hline \multirow{2}{*}{$\begin{array}{l}\text { Poverty } \\
\text { Proxy }\end{array}$} & Period & \multicolumn{2}{|l|}{$\begin{array}{l}\text { Foreign capital inflow proxy - } \\
\text { FDI }\end{array}$} & $\begin{array}{l}\text { Foreign capital inflow proxy } \\
\text { - External debt }\end{array}$ \\
\cline { 3 - 6 } & & Sign & Impact & Sign & Impact \\
\hline \multirow{3}{*}{ HDI } & LR & insig & No impact & insig & No impact \\
\cline { 2 - 6 } & SR & - & Increases poverty & + & Reduces poverty \\
\hline \multirow{3}{*}{ HCE } & LR & + & Reduces poverty & + & Reduces poverty \\
\cline { 2 - 6 } & SR & + & Reduces poverty & + & Reduces poverty \\
\hline \multirow{2}{*}{ INFA } & LR & + & Worsens poverty & + & Worsens poverty \\
\cline { 2 - 6 } & SR & + & Worsens poverty & - & Reduces poverty \\
\hline
\end{tabular}

Note: Insig = insignificant; + = positive impact; - = negative impact; LR = Long run; SR = Short run.

The explanatory power of functions 1-3, where FDI was used as a key explanatory variable are $71 \%, 74 \%$, and $98 \%$ respectively; while for functions $4-6$, where external debt was used as a key explanatory variable, were found to be $87 \%, 64 \%$ and $99 \%$ respectively. All the functions have a high explanatory power, implying a correct specification was made. The error correction terms [ECM (-1)] for all the models were found to be negative and statistically significant as expected.

Serial correlation, normality, functional form, and heteroscedasticity tests were performed on functions 1-6. All the functions passed all the diagnostic tests. Table 8 presents the diagnostic results for functions 1-6.

Table 8 Diagnostic test - Functions 1-6

\begin{tabular}{|l|l|l|l|l|l|l|}
\hline \multirow{2}{*}{ LM Test Statistic } & Results & \multicolumn{5}{|l|}{} \\
\cline { 2 - 7 } & $\begin{array}{l}\text { Function } \\
\text { (HDI, FDI) }\end{array}$ & $\begin{array}{l}\text { Function 2 } \\
\text { (HCE, FDI) }\end{array}$ & $\begin{array}{l}\text { Function 3 } \\
\text { (INFA,FDI) }\end{array}$ & $\begin{array}{l}\text { Function 4 } \\
\text { (HDI, EXD) }\end{array}$ & $\begin{array}{l}\text { Function 5 } \\
\text { (HCE, EXD) }\end{array}$ & $\begin{array}{l}\text { Function 6 } \\
\text { (INFA, EXD) }\end{array}$ \\
\hline Serial Correlation & 0.863 & 0.517 & 0.0394 & 1.813 & 2.721 & 1.0707 \\
(CHSQ 1) & {$[0.353]$} & {$[0.472]$} & {$[0.842]$} & {$[0.502]$} & {$[0.201]$} & {$[0.214]$} \\
\hline Functional Form & 1.020 & 0.462 & 1.163 & 2.022 & 1.570 & 0.882 \\
(CHSQ 1) & {$[0.312]$} & {$[0.735]$} & {$[0.413]$} & {$[0.382]$} & {$[0.210]$} & {$[0.348]$} \\
\hline Normality (CHSQ & 1.698 & 1.2394 & 1.038 & 0.337 & 2.378 & 0.479 \\
2) & {$[0.274]$} & {$[0.538]$} & {$[0.595]$} & {$[0.845]$} & {$[0.305]$} & {$[0.787]$} \\
\hline Heteroscedasticity & 2.063 & 1.581 & 0.006 & 0.561 & 1.471 & 0.009 \\
(CHSQ 1) & {$[0.151]$} & {$[0.518]$} & {$[0.940]$} & {$[0.454]$} & {$[0.204]$} & {$[0.925]$} \\
\hline
\end{tabular}


Figure 4 shows the Cumulative Sum of Recursive Residuals (CUSUM) and Cumulative Sum of Squares of Recursive Residuals (CUSUMSQ) plots for Functions 1-6.
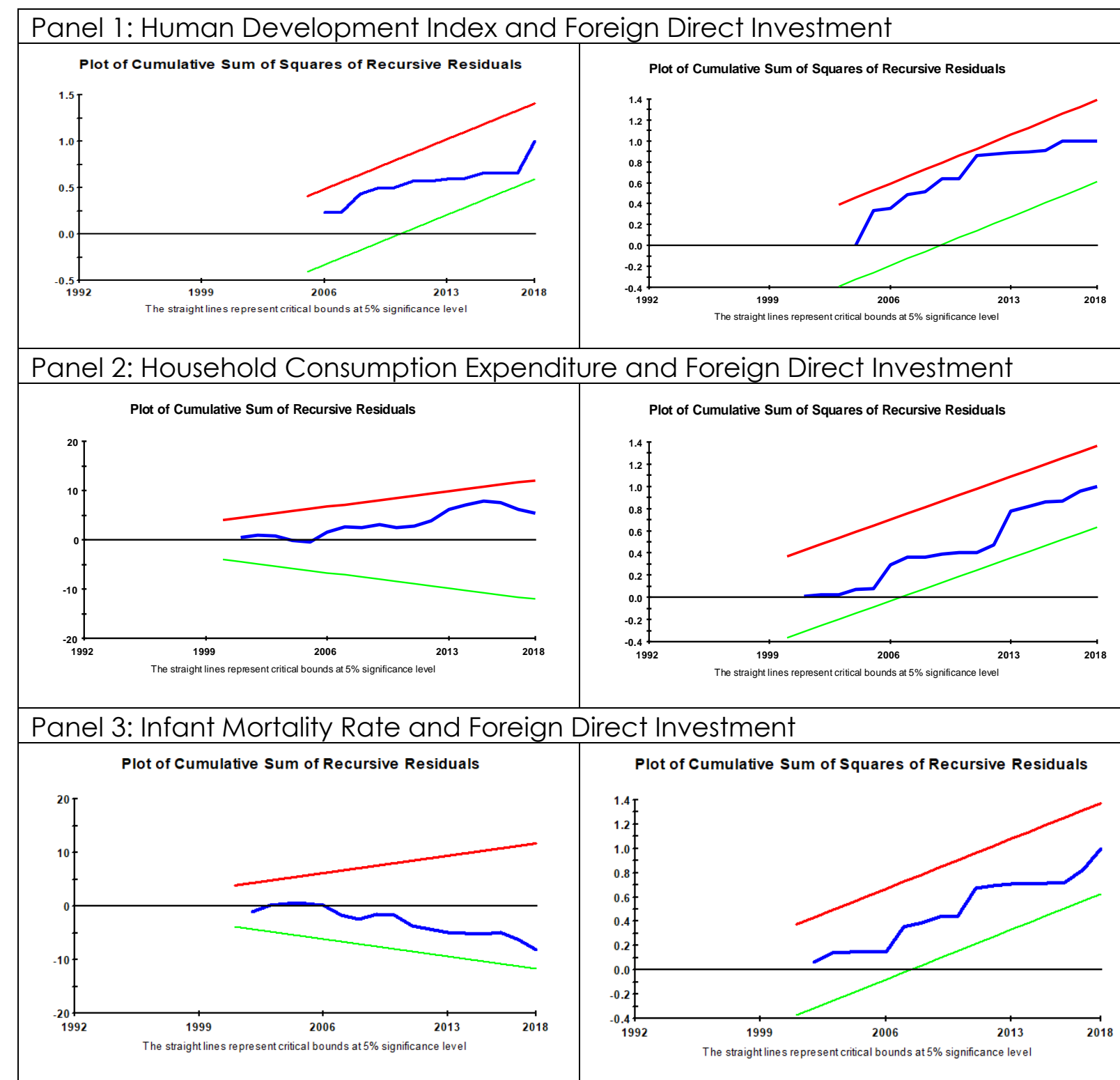

Panel 4: Human Development Index and External Debt
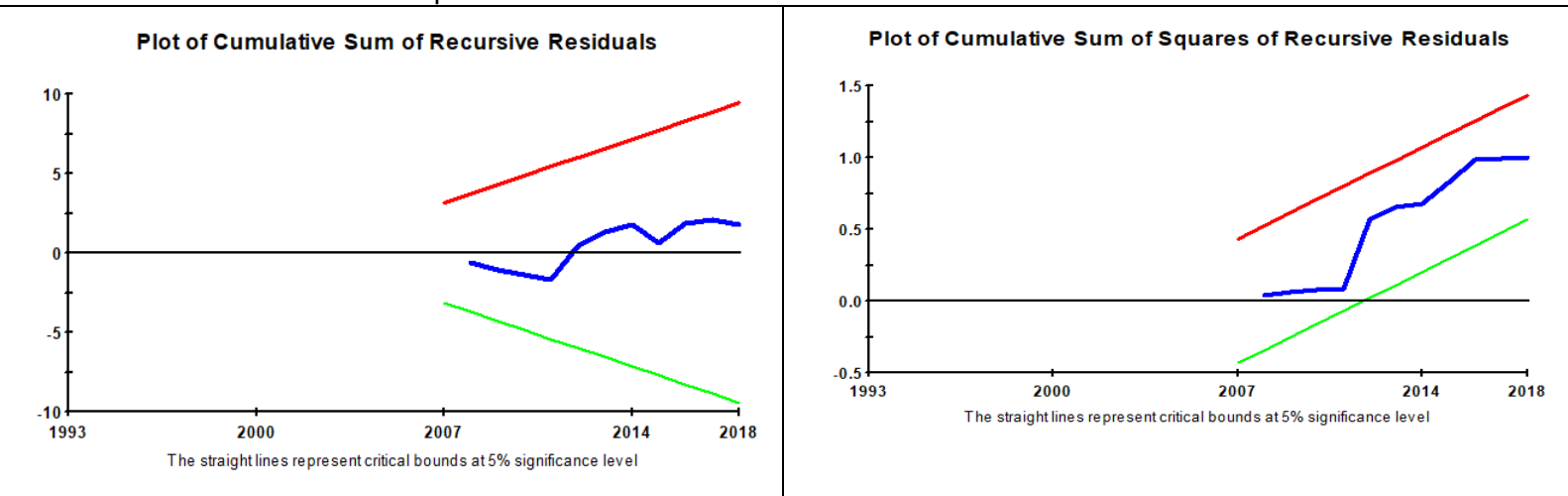

Figure 4 Plot of CUSUM and CUSUMSQ for Functions 1-6

Note: Straight lines represent critical bounds at $5 \%$ level of significance. 


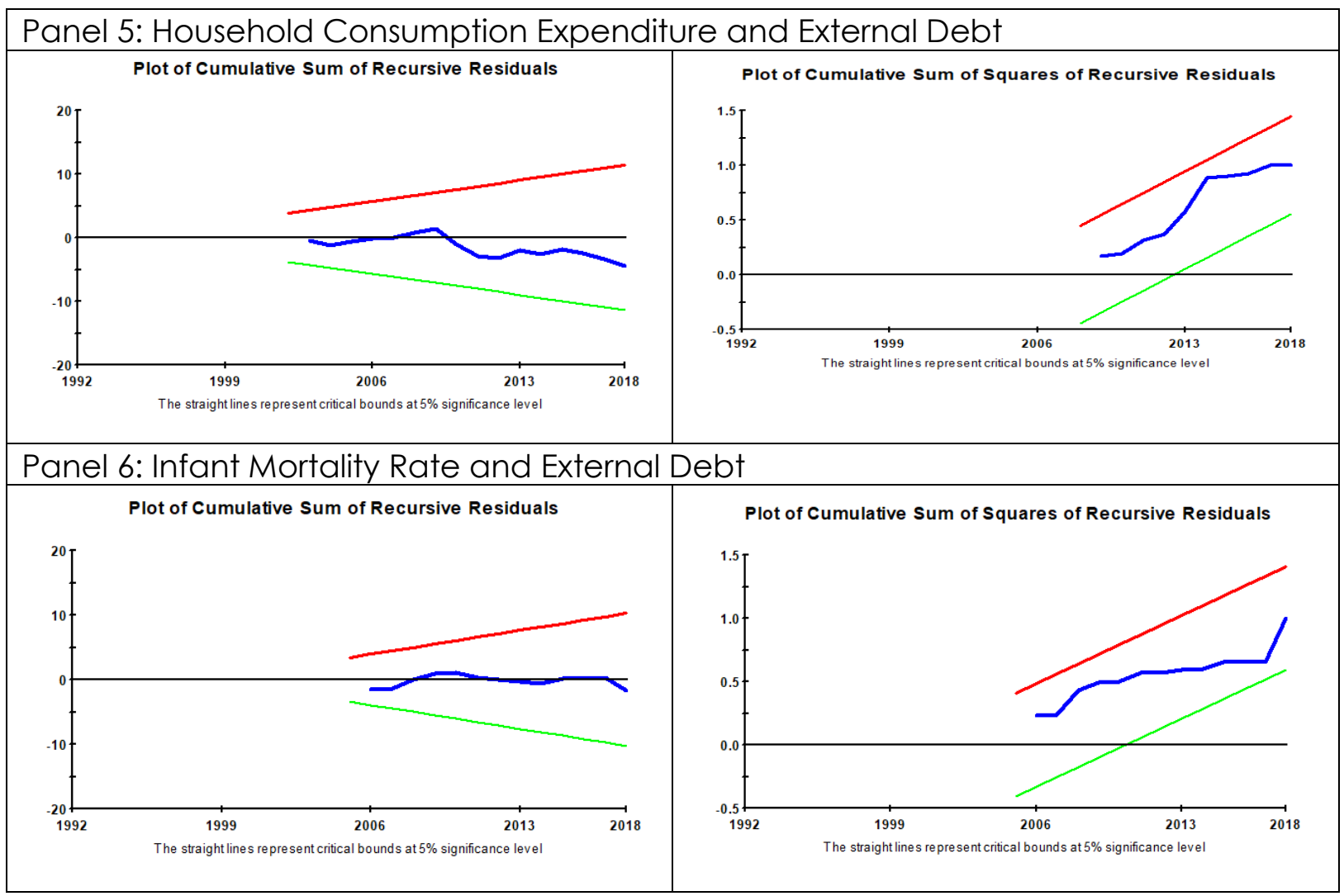

Figure 4 Plot of CUSUM and CUSUMSQ for Functions 1-6 - continued Note: Straight lines represent critical bounds at $5 \%$ level of significance.

The CUSUM and CUSUMQ plots show that parameters in the models are stable at $5 \%$ bounds.

\section{Conclusion}

This study investigates the impact of foreign capital inflows on poverty in Vietnam using annual time series data from 1990 to 2018. The study used two proxies of foreign capital inflows namely, foreign direct investment and external debt. The study attempted to close the gap in the literature by investigating the nature of the relationship between poverty and foreign capital inflows using the ARDL approach.

The results of the study have revealed that FDI reduces poverty when household consumption expenditure is used as a proxy both in the long run and in the short run. When infant mortality rate is used as a proxy, FDI was found to worsen poverty, irrespective of the time frame under consideration. The same results were confirmed in the short run, when HDI was used as a proxy, while an insignificant impact was found to exist in the long run. When external debt is used as a measure of foreign capital inflow; external debt was found to reduce poverty, in both the long and the short run, when poverty is measured by household consumption expenditure. The same results were confirmed in the short run when poverty was measured by infant mortality rate and HDI. External debt worsened poverty in the long run, when infant mortality rate was used as a proxy.

It can be concluded that the impact of foreign capital inflows on poverty in Vietnam varies depending on the type of capital flow, the poverty proxy used and the time under consideration. FDI plays a less significant role in poverty reduction in 
Vietnam as confirmed by one out of three poverty proxies. It is, therefore, recommended that Vietnam continues to support FDI in the fight against income poverty as confirmed by the significant impact of FDI on household consumption expenditure. However, policy makers need to take cognisance that the approach to poverty alleviation should be multipronged. The impact of external debt on poverty revealed the importance of external debt in reducing poverty in Vietnam. This was confirmed by three poverty proxies where external debt was found to have a negative impact on poverty. According to these findings, Vietnam can benefit from additional funds gained from external borrowing to increase support on poverty reduction programmes.

\section{References}

1. Akinmulegun, S. O. (2012). Foreign direct investment and standard of living in Nigeria. Journal of Applied Finance and Banking, Vol. 2, No. 3, pp. 295-309.

2. Akram, N. (2016). Public debt and pro-poor economic growth evidence from South Asian countries. Economic Research, Vol. 29, No. 1, pp. 746-757.

3. Ali, M., Nishat, M., Anwar, T. (2010). Do foreign inflows benefit Pakistan poor? The Pakistan Development Review, Vol. 48, No. 4, pp. 715-738.

4. Anetor, F. O., Esho, E., Verhoef, G. (2020). The impact of foreign direct investment, foreign aid, and trade on poverty reduction: Evidence from Sub-Saharan African countries. Cogent Economics \& Finance, Vol. 8, No. 1, pp. 1-14.

5. Fauzel, S., Seetanah, B., Sannassee, R. V. (2015). Foreign direct investment and welfare nexus in Sub-Saharan Africa. The Journal of Developing Areas, Vol 49, No. 5, pp. 271-283.

6. Fowowe, B., Shuaibu, M. I. (2014). Is foreign direct investment good for the poor? New evidence from African Countries. Eco Change Restruct, Vol. 47, pp. 321-339.

7. German Development Institute (2020). The comprehensive Poverty Reduction and Growth Strategy in Vietnam: Process, donor contribution and Prospects for its implementation. Available at files.ethz.ch. [06 September 2020].

8. Gohou, G., Soumare, I. (2012). Does foreign direct investment reduce poverty in Africa and are there regional differences. World Development, Vol. 40, No. 1, pp. 75-95.

9. Gorg, H., Greenaway, D. (2004). Much ado about nothing? Do domestic firms really benefit from foreign direct investment? The World Bank Research. Observer, Vol. 19, No. 2, pp. 171-197.

10.Huang C., Teng, k., Tsai, P. (2010). Inward and outward foreign direct investment and poverty reduction: East Asia versus Latin America. Review of World Economics, Vol. 146, No. 4, pp. 763-779.

11.IMF (2006). Vietnam: Poverty Reduction Strategy Paper-Annual Progress Report. Available at imf.org [06 September 2020].

12.Johansen, S., Juselius, K. (1990). Maximum likelihood estimation and inference on cointegration -with applications to the demand for money. Oxford Bulletin of Economics and Statistics, Vol. 52, No. 2, pp. 169-210.

13. Krugman, P. (1988). Financing vs Forgiving a debt overhang. Journal of Development Economics, Vol. 29, pp. 253-268.

14.Loko, B., Mlachila, M., Nallari, R., Kalonji, K., (2003). The Impact of External Indebtness on Poverty in Low-Income Countries. IMF Working Papers, No. 03/61.

15.Magombeyi, M. T., Odhiambo, M. (2017). Foreign direct investment and poverty reduction. Comparative Economic Research, Vol. 20, No. 2, pp. 73-89.

16.Magombeyi, M. T., Odhiambo, M. (2018a). Dynamic impact of FDI on poverty reduction: Empirical Evidence from South Africa. Sustainable Cities and Society, Vol. 39, pp. 519526.

17.Magombeyi, M. T., Odhiambo, M. (2018b). FDI inflows and poverty reduction in Botswana: an empirical investigation. Cogent Economics and Finance, Vol. 6, No. 1, pp. 1-15. 
18.Meyer, K. E. (2004). Perspectives on Multinational enterprises in emerging economies. Journal of International Business Studies, Vol. 35, No. 4, pp. 259-276.

19.Mohr, P. (2015). Economics for South African Students. Van Schaik Publishers, Pretoria. South Africa.

20.Narayan, P. K. (2005) The saving and investment nexus for China: evidence from cointegration tests. Applied Economics, Vol. 37, No.17, pp. 1979-1990.

21.Oyedele., S. O., Emarah, A. A., Ogege. S. (2013). External debt, debt servicing and poverty reduction in Nigeria: An empirical analysis. Journal of Economics and Sustainable Development, Vol. 4, No. 19, pp. 174-179.

22.Pesaran, M. H., Shin, Y., Smith, R. J. (2001). Bounds testing approaches to the analysis of level relationships. Journal of Applied Econometrics, Vol. 16, No. 3, pp. 289-326.

23. Quyen, N, H. (2019). Reducing rural poverty in Vietnam: issues, policies, challenges. Mekong Development Research Institute. Available at un.org [24 September 2020].

24.SDG Business Hub (2020). Vietnam-VBCSD. Available at sdghub.com [09 September 2020].

25.Shamim, A., Azeem, P., Naqvi, M. A. (2014). Impact of foreign direct investment on poverty reduction in Pakistan. International Journal of Academic Research in Business and Social Sciences, Vol. 4, No. 10, pp. 465-490.

26.Soumare, I. (2015). Does Foreign Direct Investment Improve Welfare in North Africa? Africa Development Bank.

27.Steer, L. (2020). Viet Nam's progress on economic growth and poverty reduction. Available at www.odi.org [24 September 2020].

28.Ucal, M. S. (2014). Panel data analysis of foreign direct investment and poverty from the perspective of developing countries. Social and Behavioral Science, Vol. 109, pp. 11011105.

29.UNCTAD (2008). Investment Policy Review: Vietnam. Available at unctad.org [08 September 2020).

30.UNDP (2012). Impact of Program 135-phas II through the lens of baseline and endline surveys. Available at vn.undp.org [06 September 2020].

31.UNDP (2020). Human Development Index Trends1990-2019. Available at hdr.undp.org [06 September 2020].

32. World Bank (2020). World Development Indicators. Available at www.data.worldbank.org [06 September 2020].

33.Zaghdoudi, T., Hakimi, A. (2017). Does external debt- poverty relationship confirm the debt overhang hypothesis for developing counties? Economics Bulletin, Vol. 37, No. 2, pp. 653-665.

\section{About the authors}

Mercy. T. Musakwa is a research fellow at the University of South Africa. Author can be contacted at tsile.musa@gmail.com.

Nicholas M. Odhiambo is a professor at the University of South Africa. Author can be contacted at odhianm@unisa.ac.za.

Sheilla Nyasha is a researcher at the University of South Africa. Author can be contacted at sheillanyasha@gmail.com. 